\title{
International Financial Center Shanghai: Fundamental Theory and Financial Consumer Protection Practice
}

\author{
Prof. Shudi ZHU \\ School of Law, Fudan University, Shanghai, P.R. China \\ Dr. Lina HUANG \\ School of Law, Fudan University, Shanghai, P.R. China
}

\begin{abstract}
Financial consumer protection system in the United States is well known for its comprehensiveness. However, after the eruption of the sub-prime mortgage crisis in 2007, the U.S. government realized the lack of consumer protection is one of the major causes of the financial crisis. As for China, it is urgent to establish a sound financial consumer protection system. What we should do now is to get much more involved in the research of financial consumer protection system, to find out key issues and to resolve them by learning from advanced countries, such as the United States.
\end{abstract}

KEYWORD: International financial center; Financial consumer protection; Financial legislation

\section{INTRODUCTION}

In 2009, the State Council issued Opinions on Promoting Shanghai to Speed up the Development of Modern Service Industry and Advanced Manufacturing, Building an International Financial Center and the Views of an International Shipping Center. Then, the Standing Committee of Shanghai Municipal People's Congress approved Regulations of Shanghai Municipality on Promoting the Construction of the International Financial Center, implying a new historical era of setting Shanghai as an important International Financial Center in China.

China's current financial regulation can be divided into three parts, including banking, insurance and securities, based on a market functions, and aiming at protecting consumer rights and the stability of financial system.

The U.S. financial consumer protection system is well known for its comprehensiveness. However, after the eruption of the sub-prime mortgage crisis, the U.S. government realized the lack of consumer protection is the major cause of the financial crisis.

The issuance of Blueprint for a Modernized Financial Regulatory Structure in 2008, the announcement of Consumer Financial Protection Bureau Act of 2009 and the approval of Dodd-Frank Wall Street Reform and Consumer Protection in 2010 has developed the responsibilities carried by the regulatory authorities and the measures on consumer protection.

It has become a major concern for many countries to strengthen financial consumer right protection after the crisis. As an emerging international financial center, Shanghai has a lot to learn from the U.S. financial legislation, especially from the aspect of financial consumer protection law.

\section{THE NECESSITY OF ESTABLISHING A SOUND FINANCIAL CONSUMER PROTECTION SYSTEM}

There are three fundamental roles in the legal relationship of finance: Government, operators and consumers. Operators and consumers are the major market players. Operators hold a strong position, which means consumers need more protection from the government. To establish a sound financial consumer protection system, analysis can be spread out from the following two aspects:

\subsection{Targets}

\subsubsection{To Regulate the Financial Operation Behavior}

Financial operations are prone to pursue profit maximization by providing more financial products under limited rationales. The inadequate rational behaviors can lead to negative result and make malfunction of financial market, or even worse, an overwhelming economic system crisis, such as the US sub-prime mortgage crisis. Thus, government should take necessary prevention for the potentially high risk activities in order to increase financial consumer's confidence and protect their rights. 


\subsubsection{Information Disclosure Between Financial Operators and Financial Consumers}

The complexity and professionalism of financial products lead to asymmetric information. Financial consumers mainly rely on the information provided by financial services when purchasing financial products. If their right to know are breached, they will suffer loss. Financial consumer protection can be achieved by institutionalized education and information disclosure, etc.

\subsubsection{Interest Balance Between Financial Operator and Financial Consumer}

Financial consumers are vulnerable due to a lack of special knowledge to purse legal remedy. Moreover, such problem can not be resolved by market itself. One of the most immediate approach is for the government to implement laws and to protect consumer by realizing the substantive equity between the parties of the transaction. See Table 1.

Table 1.Regulation in International Financial Center Shanghai.

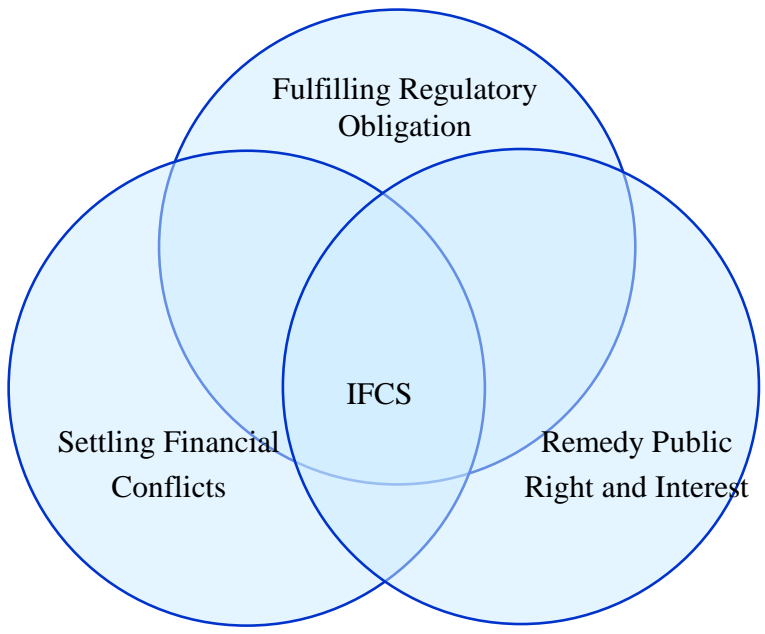

* IFCS = International Financial Center Shanghai.

\subsection{Significance of Value}

To establish a sound financial consumer protection system, measures should be taken:

1. To protect financial consumer interest and to evaluate financial consumption level;

2. To enhance the competition of financial industry and protect interests of financial operators;

3 . To promote a healthy development of financial markets and to maximize public interest.

\section{CONSUMER PROTECTION LEGAL SYSTEM IN CHINA}

Since the beginning of last 90s, China issued series of rules, regulations and other administrative standard documents, including Bank Law, Commercial Bank Law, Securities Law, Insurance
Law, the People's Republic of China Banking Regulation and Supervision Law, which systematically constitute the fundamental legal system for banking, securities, insurances, futures and other financial industries in the segregated financial system. From the perspective of financial consumer protection, current China financial consumer protection situation and problems can be summarized as follows:

\subsection{Government's Vagueness on Financial Consumer Protection}

Financial legislation should focus on the safety and effectiveness of financial institutions, without ignoring the interests of consumers. China's current goals in legal protection of consumer protection are not clear.

\subsection{Incomplete Financial Legislation on Consumer Protection and Financial Consumer Rights}

China's financial consumer protection laws can be divided into three levels: the first one includes People's Republic of China Consumers' Rights and Interests Protection Law, of which most rules about consumer rights and operator responsibilities are not applicable to finance consumption. The second one includes Commercial Bank Law and People's Republic of China Banking Regulation and Supervision Law, which focus on financial regulation, deposit security and confidentiality. The third one includes departmental rules and regulations issued by the People's Bank of China and the China Banking Regulatory Commission, formulating restrictive clauses but lacking specific operational methods.

\section{LEARNING FROM THE U.S. FINANCIAL CONSUMER PROTECTION SYSTEM}

\subsection{The Protection of Consumers' Rights and Interests}

It is one of the two basic goals for the U.S. financial legal system to protect consumers' rights and interests. According to the above mentioned U.S. financial legal norms, the main content of the American Financial Consumer Protection Law includes consumers' rights to know, the protection of consumers' privacy, obligations, safety and fair dealing. After the sub-prime crisis in 2008, the Obama government realized that the majority of consumers lack professional financial knowledge. They are faced with difficulty in identifying potential traps lying in the financial products. Therefore, it's necessary for the agencies to strengthen their responsibility to reveal information to consumers. 


\subsection{Protection Agencies}

The U.S. federal regulatory system for financial consumers protection is consisted of Federal Reserve, Office of the Currency Comptroller, the Federal Deposit Insurance Corporation, Office of Thrift Supervision and so on. Protection of consumers is one of their core tasks, along with other daily routine (such as financial security and prudential supervision). Now these financial protection agencies are established in accordance with the Dodd-Frank Wall Street and Consumer Protection Act, aiming at supervising all kinds of financial products such as mortgage loans of house and car; credit card; check and savings accounts, etc. Also, the duty for protecting financial consumer is now transferred to these agencies.

\subsection{The Mechanism for Disputes Settling}

In the United States, banks deal with the consumers' complaints by themselves. Cases that can not be resolved on their own will be submitted to regulatory agencies such as Federal Reserve Board, Office of the Comptroller of the Currency or the Federal Deposit Insurance Corporation, etc. If the consumer's rights can not be protected through above agencies, it will be resolved through the judicial mechanism for disputes settling. Consumer's small claims and class actions, as the most common choices, will be applied.

\section{SUGGESTIONS FOR THE LEGISLATION OF SHANGHAI FINANCIAL CONSUMER PROTECTION LAW}

\subsection{The Definition of Financial Consumers}

The definition of financial consumers is the primary legal concept in financial consumer protection system. It can be defined as: those who buy and use financial products or receive financial service. They are not only consumers as natural person but also include legal person as representative of a company. Usually, they do not work for professional financial agencies and are not equipped with professional financial knowledge, thus are in a disadvantaged situation in the trade.

\subsection{The Purpose and Principles of Legislation}

The legislation of Shanghai Financial Consumer Protection Law is aimed at protecting the legal rights and interests of consumers, balancing the interests of parties, maintaining the stability of financial order and realizing the maximization of the social and public interests.

\subsection{Legislation Content}

To achieve equal protection, Shanghai Financial Consumer Protection Law should include protection of traditional and newly-invented financial products that consumers buy and use, as well as all kinds of financial service that consumers would receive.

\subsection{Rights and Interests in Financial Consumer Protection}

The rights and interests of financial consumers can be divided into nine categories:

(1) Safety right; (2) Right to know;(3) Freedom of choice;(4) Fair trade Right;(5) Compensation right; (6) Right of association; (7) Right to inquire; (8) Right to be respected; (9) Supervision rights.

\subsection{Consumer Protection Agency}

The current financial regulatory system in China follows specialized supervision. We can refer to a series of protection modes adopted recently by the USA so as to protect our financial consumers effectively. Considering the important role of Shanghai in legislation work in China, it is recommended that shanghai financial office should take the lead in setting up a coordination and supervision mechanism among agencies. Meanwhile, we suggest that the State Council might approve the establishment of Shanghai Financial Regulation Headquarter.

\subsection{Mechanism for Settling Disputes}

As for the Financial Consumer Dispute Resolution Mechanism in the U.S. and the existing laws in China, the Shanghai Financial Consumer Dispute Resolution Mechanism can be divided into following interrelated aspects:

(1) Establish and improve the complaint resolving system to enable the banks, and other financial institutions to handle and solve consumer complaints on their own.

(2) Establish a complaint resolving system under Shanghai Financial Office in charge of unified coordination in case that some financial agencies can't resolve consumer complaints.

(3) Associate the above mentioned complaint resolving system with Shanghai Consumer Rights and Interests Protection Association to resolve financial consuming disputes.

(4) Establish a series of procedures for handing or arbitrating financial consuming dispute in detail by arbitration commission.

(5) As for judicial review, we suggest that the National People's Congress and the Supreme People's Court might support Shanghai to make innovation. That is to say, for example, NPC 
standing committee may approve the establishment of financial court in the existing court system.

\section{CONCLUSION}

Modern government is administrative government; most part of modern life can be seen as the product of the executive authority's activity. Legal norms and principles about the regulation of specialized administrative agency's activity constitute various departments of administrative law; and the administrative law theory on it constitutes a subadministrative law. Hence, the theoretical system of administrative law can be divided into two parts: the general theory of administrative law and sub-theory of administrative law. The general theory of administrative law mainly focuses on the general system of administrative law, while the sub-theory of administrative law dwells on specific fields of administrative law matters, such as educational administration law, district administration law, and customs administration law, and so on.

To sum up, the legal system for building Shanghai International Financial Center is an organic part of
China legal system. Therefore, the implementation of the above Suggestion will contribute to the consistent reform and innovation of the whole legal system in China.

\section{REFERENCES}

[1] A Conference on Consumer Protection in Financial Product Markets, http://www.clevelandfed.org/research/policydis/pdp29.cfm

[2] Stephen G. Breyer, Richard B. Stewart, Cass R. Sunstein, Matthew L. Spitizer, Administrative Law and Regulatory Policy: Problems, Text, and Cases (Fifth Edition), Aspen Law \& Business, New York, 2002; PP. 5-15.

[3] Lee Hudson Teslik, The US Financial Regulatory System, http://www.cfr.org/publication/17417/us_financial_regulat ory_system.html

[4] Zheng Yongnan, New Reign under Zhu, Hongkong, 1999, pp121-122.

[5] Rechard Hynes and Aric A Posner, the Law and Economics of Consumer Finance American Law and Economics Review, Vol. 4, No. 1, 2002, pp. 168-207.

[6] Jianmiao Hu: Administrative Law, Beijing: Law Press, February 2003, 2nd edition, p. 38-39. 